\title{
Особливості оперативного лікування поєднаних пошкоджень трахеї та стравоходу в шийній ділянці
}

\author{
І. Д. Дужий, С. О. Голубничий, Я. В. Хижня, О. В. Кравець
}

Сумський державний університет

\section{Peculiarities of operative treatment of combined injuries of trachea and esophagus in cervical portion}

\author{
I. D. Duzhyi, S. O. Holubnichyi, Ya. V. Khyzhnia, O. V. Kravets
}

Sumy State University

\begin{abstract}
Пошкодження стравоходу і трахеї займають особливе місце поміж травм шиї з огляду на їх топографо-анатомічне розташування та локалізацію у клітковині шиї і середостіння, які сполучаються між собою чи переходять одна в іншу. Це має принципове значення, оскільки запалення будь-якого генезу неодмінно «спускається» 3 шийних відділів до середостіння з розвитком поліорганної недостатності, що може мати фатальні наслідки. Встановлено, що чим триваліший період від моменту отримання травми до моменту госпіталізації у спеціалізоване відділення, тим несприятливіший результат. Так, у разі виконання оперативного втручання в строки до 6 год від моменту отримання травми летальність становить 12 - 14,5\%; у разі виконання операції пізніше 12 год летальність збільшується удвічі - до 24 - 28\%; у разі виконання операції пізніше 24 год летальність зростає до 48 - 56\% [1, 2]. Такі показники летальності $€$ наслідком головним чином ускладнень, які розвиваються безпосередньо після отриманої травми взагалі і стравоходу зокрема. Уникнути несприятливих результатів лікування травм шиї, у тому числі трахеї і стравоходу, можливо лише шляхом своєчасного виконання оперативних втручань [3, 4].

Воєнні дії на сході країни супроводжуються застосуванням противником найсучаснішої зброї вибухово-розривної дії, що призводить до пошкоджень як грудної клітки, так і шиї та розташованих у ній органів. Так само ці органи $є$ «мішенями» для снайперів. У доступній літературі останнього часу ми не знайшли повідомлень щодо поєднаного пошкодження стравоходу і трахеї, кожне з яких може бути небезпечним для життя, що вказує на актуальність даної проблеми.

За останні 5 років ми спостерігали 5 постраждалих з травмами шиї, у 1 з них було пошкодження стравоходу і трахеї внаслідок вогнепального поранення. Наводимо клінічне спостереження.
\end{abstract}

Постраждалий К., 14 р., мешканець села, о 14 год був поранений «жаканом» 3 мисливської рушниці у праву половину шиї з відстані 5 м. Через 40 хв доставлений у хірургічне відділення районної лікарні. Непритомний, блідий. По середньо-боковій поверхні шиї рвана рана, з якої у процесі дихання «сичить» повітря, а хворий водночас покашлює.
Артеріальний тиск 90/60 мм рт. ст., пульс 120 за 1 хв, ниткоподібний, ритмічний. Начмед негайно замовив через санітарну авіацію торакального хірурга.

Травмований негайно доставлений в операційну. Підключено дві вени. Налагоджено введення в одну з них плазми, в іншу - реополіглюкіну. Надалі розчини вводили за протоколом лікування шоку. Одночасно з канюлюванням вен та інфузійною терапією проведено ревізію рани шиї. Встановлено наявність дефекту трахеї по середній лінії шиї. Виконано інтубацію трахеї через іiі дефект з роздуванням манжети нижче «трахеального діастазу». Розпочато нейролептаналгезію.

Через годину після госпіталізації в хірургічне відділення травмованого оглянув торакальний хірург. Встановлено, що впродовж 1,5 трахеального кільця (між III і IV кільцями) вирвана стінка трахеї. Верхній край рани трахеї відносно рівний і проходить по міжкільцевому проміжку, нижній край - «хвилеподібний» і проходить по нижче розташованому трахеальному кільцю. Задньо-бокова стінка трахеї на цьому рівні вирвана, краї рани трахеї нерівні, кровоточать. Основна рвана рана шиї розпочинається справа по задньому краю груднинно-ключично-соскоподібного м'яза, направляється до трахеї і проходить між нею і стравоходом. На передній стінці стравоходу вирвана рана розмірами 1,5×2 см. Більший розмір рани був вертикальним. Краї рани стравоходу нерівні, кровоточать. Рановий канал поширюється вліво позаду лівого груднинно-ключично-соскоподібного м'яза, далі - під трапецієподібний м'яз по внутрішніх відділах лопатки і закінчується біля ії нижнього кута. Після зупинки кровотечі із м'яких тканин провели детальну ревізію рани і встановили, що магістральні судини не пошкоджені.

Вирішено виконати пластику стравоходу місцевими тканинами. Як пластичний матеріал використано груднинноключично-соскоподібний м'яз. Для пластики стравоходу використано лівий м'яз, який мобілізували в нижній третині на половину об'єму. Спочатку були накладені шви по периметру рани стравоходу через $3-4$ мм, після чого ними було прошито і зав'язано клапоть груднинно-ключично-соскоподібного м'яза. Другий ряд швів накладено пери- 
ферійніше від першого з кроком у 4 - 5 мм. Пластику стравоходу виконували на товстому зонді.

Після цього були накладені шви на хрящову частину трахеї між III і IV кільцями. Проведена мобілізація клаптя правого груднинно-ключично-соскоподібного м'яза, як і лівого, у нижній його третині довжиною 35 мм на половину об'єму. Аналогічно накладенню швів стравоходу спочатку були накладені провізорні шви на задньо-бокові відділи трахеї відповідно до їі рани, після чого підшито клапоть підготовленого м'яза. Додаткових (другий ряд) швів не накладали. Рану (дно іiі) засипали доксицикліном, дренували двома іригаторами для постійного відсмоктування екстравазату і введення антибіотиків. Поставлені гумові випускники. Введено назогастральний зонд для харчування. Підборіддя приведено до руків'я груднини. Накладено шкірно-м'язові шви на рівні нижньої щелепи і ключиці для попередження натягу в зоні швів трахеї і стравоходу.

Відразу після виконання основного втручання під кутом лівої лопатки виконано розріз шкіри, підшкірної клітковини, розшаровано м'язи і видалено стороннє тіло, яким виявився пиж від мисливського патрона. Рановий канал під лопаткою дреновано мікроіригатором для відсмоктування екстравазату і введення антибіотиків.

У післяопераційному періоді призначені антибіотики внутрішньом'язово та для введення в мікроіригатори на шиї і під лопаткою, постійне відсмоктування екстравазату із рани на шиї та кожні 2 год із рани під лопаткою. Гастральний зонд на 5-ту добу замінено на тонкий через просвіт попереднього.

Перебіг післяопераційного періоду без ускладнень. Іригатори видалено на 6-ту і 8-му добу. Гумові випускники з післяопераційної рани на шиї видалені після видалення іригаторів через 2 доби. Шкірні шви між щелепою і ключицею знято після зняття шкірних швів на рані через 3 доби (на 12-ту добу).

За даними В. В. Бойка і співавторів [4], травмованих з пораненнями шийного відділу госпіталізують від 2 до 24 год з моменту катастрофи, що небезпечно, адже ризик смерті за таких пошкоджень збільшується кожної години на 5\% [3] через рівень мікробної контамінації рани та розвиток гнійних ускладнень. У пацієнта, якого ми спостерігали, ці ускладнення вдалося попередити, оскільки його оперували вже через 120 хв від моменту отримання травми, що стало можливим за рахунок добре налагодженої роботи служби екстреної медичної допомоги та медицини катастроф: відразу після отримання повідомлення про поранення диспетчер районної лікарні направив машину швидкої допо- моги на місце катастрофи й одночасно викликав торакального хірурга з обласного центру. Окрім цього, пластику пошкоджених стравоходу і трахеї виконували неушкодженими груднинно-ключично-соскоподібними м'язами, які мали достатне кровопостачання. Орошення доксицикліном, який стимулює фібропластичні можливості пошкоджених тканин, сприяло попередженню інфекційних ускладнень і заживленню ран первинним натягом.

Дане спостереження цікаве тим, що травма шиї отримана від пострілу пижом із мисливської рушниці. Пиж пробив бокову стінку шиї, не пошкодивши магістральних судин, пройшов між шийним відділом трахеї і стравоходу, вирвавши задню стінку трахеї і передню стінку стравоходу, «пірнувши» через ліве надпліччя, пройшов поза лопаткою і застряв під іiі кутом. Пластику дефектів трахеї і стравоходу виконано клаптями правого і лівого груднинно-ключично-соскоподібних м'язів за типом первинної хірургічної обробки рани, що унеможливило інфікування зони пошкодження за рахунок ії герметизації і приживлення клаптів м'яза первинним натягом. 3 цією метою до зони швів підводили доксициклін. Зони швів на дефектах пошкоджених органів у післяопераційному періоді орошували антибіотиками, навколо них постійно створювали розрідження шляхом відсмоктування екстравазату. Отриманий результат дає підставу рекомендувати описаний алгоритм для хірургічного лікування поєднаних та ізольованих травм трахеї і стравоходу в ділянці шиї з максимальним збереженням їх тканин, для чого слід застосовувати м'язи шиї, найбільш придатним із яких є груднинно-ключично-соскоподібний м'яз.

\section{References}

1. Zamjatin PN, Baranova NV, Kucenko TA. Diagnosticheskie osobennosti zakrytoj travmy grudnoj kletki. Medicina neotlozhnyh sostojanij. 2008;(6):71-3. [In Russian].

2. Komarov BD, Kanshin NN, Abakumov MM Povrezhdenyia pyshchevoda. Moskva: Medicina; 1981. 175 p. [In Russian].

3. Alekseenko VE, Anishhuk VP, Zherebkin VV. Problemy okazaniia pomoshhi postradavshim s mnozhestvennoi i sochetannoi travmoi na dogospitalnom etape. In: Problemi viyskovoi ohoroni zdoroviia. 2014; 42(2): 11722. [In Ukrainian].

4. Boyko VV, Syzyi MYu, Makarov VV, Shevchenko O M, Likhman VM, Gulya€va DYu, et al. Khirurhichna taktyka pry poranenniakh hlotky ta shyinoho viddilu stravokhodu. Kharkivska khirurhichna shkola. 2016;(5):1822. [In Ukrainian]. 